\title{
電力・エネルギー部門誌の編修と 部門全国大会の実施について
}

\author{
電力・エネルギー部門特別委員会 \\ 副委員長 芹 澤 康 夫
}

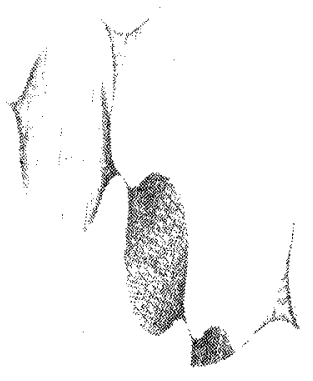

電気学会の部門活動の第一の柱である電力・エネル ギー部門誌第 1 号が, 部門誌編修委員会を中心に関係 の方々の御尽力により，発刊できましたことを心から お慶び申し上げます。とともに，本部門誌が巻を重ね るごとに会員の皆様にますます親しまれ，研究成果の 発表, 新しい技術情報の入手や, 会員相互のコミュニ ケーションの輪を広げるのに役立つよう, 大きく育っ ていくことを期待します。

電力・エネルギー部門誌は, 基本的には電気学会論 文誌 $\mathrm{B}$ 分冊を引継き，新しい制度の基本方針に沿つ て,内容の充実と発展を図ったものです。促って, 会 員の㫮様の研究成果である論文を中心に構成され，こ れに部門に関倸の深い最新の技術情報, 技術動向，技 術委員会や研究会などの活動状況などを加えて, 読者 に提供することを編修企画の方針としております。

また，我が国の電力・エネルギー部問関連技術の世 界における位置付けや今後の役割りを考えるとき，我 が国だけでなく，海外会員の拡大とその方々へのサー ビスについても配慮する必要があります。そのため, まず英文による論文投稿の受入れと共に, 論文, 解説 記事には英文表題と英文アブストラクトを付け加える ことにいたしました。

部門誌の内容としては, 当面次のものを予定してい ますが，試行を重かながら逐次新しいアイデアを組込 んでいく予定です。

（1）論文特集 一般論文, 研究開発ノートを中

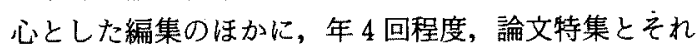
に関連する解説を組みます。現在，次の 4 課題を用意 致しておりますので，奮って御投稿ください。

・電力・エネルギー分野のエキスパートシステム 平成 2 年 4 月㝍

・ $\mathrm{SF}_{6}$ ガスおよび $\mathrm{SF}_{6}$ ガス絶緑機器 平成 2 年 7 月号

- 電力系統の電圧安定性

・雷放電と耐雷技術 平成 2 年 10 月号 平成 3 年 1 月号
これ以後については, 電力・エネルギー部門全国大 会への投稿論文の動向, 研究会活動などを踏まえて, 順次時代の要請にこたえた論文特集を企画していく予 定です。

（2）特集解説・一般解説 学会雑誌が全会員を 対象に編集され，電気関係の全分野をカバーしている のに対し，当部門誌では，特集解説・一般解説として 電力・エネルギー分野に何らかの関係のある方々を対 象に, より専門色の強い課題，ないし強い関心をもた れる課題を選び，論文特集のない月に企画する予定で す。適切な課題について, 部門誌編修委員会に御提案 を扔寄せ下さい。

（3）調査研究委員会レポート 電力・エネルギ 一部門の技術委員会 (現在 7 委員会), 調查専門委員 会 (現在 34 委員会) の活動状況, 内容, トピックス などを月 3 件程度揭載の予定です。

（4）研究グループ紹介 大学, 研究機関, 電力 会社, メ一力, その他の機関の研究開発グループのプ ロフィールを順次紹介いたします。

（5）海外駐在記事比較的長期間海外に駐在さ れている方，あるいはされていた方に，電力・エネル ギー分野を取巻く各国の環境や技術動向，トピック ス, 経験談など，肩を張らずに読めるように紹介して いただきます。

（6）その他記事学界情報, 読者の声, 論文委 員会ニュース，会告，投稿のお誘い，広告などを通じ て会員とのコミュニケーションを活発にしたいと考え ています。

初年度の部門誌年間割当ページは一応 984 ページ で, 論文は年間 72〜96 件を予定して扔ります。しか し部門制移行に伴い, 論文数の増加が予想されますの で，その場合は論文以外の記事で調整するなどフレキ シブルな運用をしていく方針です。

次に, 電力・エネルギー部門の会員の方々の研究成 果や, 技術開発の成果, 新しい発想の発表と会員相互 
のコミュニケーションと懇親を図るための, いま一つ の柱として, 電力・エネルギー部門全国大会を開催す ることにしました。第一回大会は平成 2 年 7 月 24 日 〜26日に横浜国立大学で実施します。これ以後も当 面は年 1 回の開催とし, 開催場所は幅広く各地で持回 る方針で進めておりますが，具体的な開催間隔，場 所, 時期などについては, 電気学会本部や支部の行 事, 研究会活動などとの整合を図りながら, 順次意つ めていく予定です。この大会では，採録された論文が 世間から正しく評価されるように，常置の諭文査読機 関を設けて，投稿論文の查読をいたします。また、こ
の大会の国際化への指向の第一歩として, 部門誌同様 $に$ ，英文論文の受入れと，和文論文には英文表題と， 英文アブストラクトを付け加えることにいたしまし た。また優れた論文の表彰も行う予定です。 部門誌の編集, 部門全国大会の運営は部門制試行中 で流動的です。会員の皆様の忌憚のない御意見，御提 案により, 電力・エネルギー部門の今後の発展の基礎 固めができ，若い方々が自由にのびのびと活躍できる 場が広がっていくことを期待します。

(平成元年 11 月 7 日受付) 